Tibuana

Journal of applied Industrial Engineering-University of PGRI Adi Buana

DOI : https://doi.org/10.36456/tibuana.4.01.3177.44-48

p-ISSN 2622-2027

$e$-ISSN 2622-2035

\title{
Design of Table Chair Flexibility Products Using Antopometry Methods to Minimize Land Use
}

\author{
Yanatra Budi Pramana ${ }^{1}$, Indra Dwi Febryanto ${ }^{2}$ \\ ${ }^{1,2}$ Industrial Engineering Department, Faculty of Industrial Technology University of PGRI Adi Buana \\ Surabaya \\ Email : p_yanatra@unipasby.ac.id
}

\begin{abstract}
In an increasingly advanced era, all property or home furniture is required to have a renewable innovation and efficiency. This is because property or home furniture currently has a very large mass or size. Large furniture sizes such as chairs and tables have an average area of $500 \mathrm{~cm} 2$. Almost $90 \%$ of Indonesian people have tables and chairs as the contents of their household furniture. Not only functioned at home, in restaurants, cafes, malls, offices, in parks and all places where if there is interaction between humans, there must be chairs and tables as places for interaction. But sometimes the owners of chairs and tables often complain about the size of the tables and chairs, so they need a large enough area to place these two items. The problem that exists in society today is the narrowing of empty land in one place. Sometimes there is home furniture that is not ergonomic, such as a chair that is too high, a table that is too low and so on. By using this anthopometric method, the measurements obtained include a chair along the 95th percentile $25 \mathrm{~cm}$, chair length $33 \mathrm{~cm}$ 95th percentile, table length $68 \mathrm{~cm} 5$ th percentile, chair height $39 \mathrm{~cm}$ 5th percentile, table height $69 \mathrm{~cm} 5$ th percentile, and finally lower surface height. a table of $54 \mathrm{~cm}$ on the 95 th percentile, and it is hoped that the manufacture of a chair flexibility table product design can overcome all the problems of land limitations that exist in today's society.
\end{abstract}

Keywords: Table chair flexibilty

\section{INTRODUCTION}

Chairs and tables are household furniture that are commonly used by many people. The definition of a chair itself is a household piece of furniture that is usually used as a seat, which generally has 4 legs that are used to support the weight on it. Meanwhile, the notion of a table is a piece of furniture that generally has a flat surface and legs as supports, which have various forms and functions. In general, tables are often paired with chairs or benches. So basically a table and a chair are two different parts but their functions are very complementary to one another, so that a table must also be equipped with a chair as a seat. If there is a table without chairs, the function of the table will be less effective or the use of the table will be reduced, especially if the table in question is a table for eating, a table for studying, and a table for work, because of the various types a table that is used for some of the above activities will really need a chair to support the function of the table. On this problem, our group made an innovation, namely making flexible chairs and tables (table chair flexibility) using the anthopometric method. The purpose of making this flexible chair flexibility is to reduce the size of the chairs and tables that are quite large, and can be placed on a small area or place. Because the concept of a table chair flexibility is a chair and table combined into one that has a level of ease of storage and is easy to move from one place to another. As well as reducing the size and chair flexibility table with the tools in it. The development of a chair flexibility table using the anthopometric method is carried out in several stages, namely the first measurement of the physical body of the human body, after that calculating each percentage of each human body size used and finally looking for the exact size that will be used in manufacturing. Physical human bodies that are used include arm length, waist length, half back knee, knee height, elbow height in a sitting position and folded knee.

\section{Methodology}

The process for making a chair flexibility table consists of several steps, including: Determination of Sample Data Sampling data were obtained from members of this group, amounting to 21 people using a questionnaire method. Physical Measurement, Measurements of human physical measurements that will be 
Tibuana

Journal of applied Industrial Engineering-University of PGRI Adi Buana

DOI : https://doi.org/10.36456/tibuana.4.01.3177.44-48

p-ISSN 2622-2027

$e$-ISSN 2622-2035

carried out include knee folding, arm length,

the standard deviation the method of calculating waist length, half back knee height, knee height and elbow height in a sitting position, Anthopometric Calculations. The calculated calculation is the mean, standard deviation, 5 and 95 percent. In determining the mean, the method of calculating it is by averaging the size of one of the physical human bodies, whereas if calculating it is:

$\mathrm{SD}=\sqrt{ }\left(f \mathrm{x}^{2} / \mathrm{N}\right)$

Meanwhile, if you calculate the percentage 5 and 95 how to calculate it as follows: Presentile 5th $=$ $\mathrm{X}-1,645 . \mathrm{SD}, 95$ th percentile $=\mathrm{X}+1,645 . \mathrm{SD}$

Table 1. Body Size Data

\begin{tabular}{|c|c|c|c|c|c|c|c|}
\hline No & Name & $\begin{array}{l}\text { Arm in } \\
\text { Lengh }\end{array}$ & $\begin{array}{l}\text { Waist } \\
\text { Length }\end{array}$ & $\begin{array}{c}\text { Folds Knee } \\
\text { Back }\end{array}$ & $\begin{array}{l}\text { Knee } \\
\text { Height }\end{array}$ & LLTK & $\begin{array}{l}\text { Elbow beight in a } \\
\text { sitting position }\end{array}$ \\
\hline 1 & Alvin Febriante & 80 & 33 & 25 & 60 & 49 & 75 \\
\hline 2 & Mimien Yanuar & 65 & 27 & 19 & 30 & 37 & 69 \\
\hline 3 & Deny Puji 5 & 70 & 30 & 20 & 52 & 40 & 72 \\
\hline 4 & Abdal Haqi & 75 & 31 & 23 & 55 & 44 & 72 \\
\hline 5 & Alaikal Firdaus & 73 & 31 & 22 & 53 & 43 & 72 \\
\hline 6 & Ade Ivan & 72 & 30 & 23 & 52 & 40 & 71 \\
\hline 7 & Hilman Fikri & 77 & 32 & 26 & 58 & 44 & 73 \\
\hline 8 & Ade Ryan & 74 & 31 & 24 & 52 & 41 & 72 \\
\hline 9 & $\begin{array}{c}\text { Diki } \\
\text { Prastyawan }\end{array}$ & 70 & 32 & 23 & 50 & 39 & 70 \\
\hline 10 & Edi Nasnulioh & 71 & 30 & 21 & 50 & 40 & 71 \\
\hline 11 & Eriko Habib & 75 & 32 & 24 & 53 & 44 & 71 \\
\hline 12 & Danarg Sulima & 74 & 30 & 24 & 52 & 41 & 72 \\
\hline 13 & $\begin{array}{c}\text { Fikri } \\
\text { Rahmawan }\end{array}$ & 75 & 31 & 24 & 53 & 40 & 72 \\
\hline 14 & $\begin{array}{l}\text { IISaipul } \\
\text { Ansoi }\end{array}$ & 76 & 32 & 23 & 52 & 38 & 72 \\
\hline 15 & Denka Pundita & 68 & 30 & 23 & 53 & 39 & 71 \\
\hline 16 & $\begin{array}{l}\text { Yusril Rizal } \\
\text { Abdullch }\end{array}$ & 77 & 30 & 23 & 52 & 41 & 69 \\
\hline 17 & Fand Nur & 72 & 29 & 22 & 53 & 41 & 70 \\
\hline 18 & M. Ajlz & 78 & 32 & 23 & 54 & 40 & 72 \\
\hline 19 & Ranu Wibowo & 73 & 31 & 22 & 53 & 41 & 71 \\
\hline 20 & $\begin{array}{l}\text { Mustaghfini } \\
\text { Asror }\end{array}$ & 80 & 32 & 23 & 53 & 40 & 70 \\
\hline 21 & Yayan Sopian & 77 & 30 & 23 & 53 & 40 & 70 \\
\hline
\end{tabular}


Tibuana

Journal of applied Industrial Engineering-University of PGRI Adi Buana

DOI : https://doi.org/10.36456/tibuana.4.01.3177.44-48

p-ISSN 2622-2027

$e$-ISSN 2622-2035

\section{RESULT AND DISCUSSION}

This chapter will include the amount of calculations for the anthopometric data and flexibility tables, Anthopometric the size of the finalization in making chair calculations for knee height:

Table 2. Data Calculation of Anthopometry

\begin{tabular}{|c|c|c|c|c|c|c|}
\hline No & Name & $\begin{array}{c}\text { Knee } \\
\text { Height }\end{array}$ & $\mathrm{F}$ & $(\mathrm{x})$ & $\mathrm{X} 2$ & $\mathrm{X} 2 . \mathrm{F}$ \\
\hline 1 & Alvin F & 60 & 1 & 7.95 & 63.24 & 63.24 \\
\hline 2 & Mimien & 30 & 1 & -22.05 & 486.10 & 486.10 \\
\hline 3 & Deny P & 52 & 1 & -0.05 & 0.00 & 0.00 \\
\hline 4 & Abdul Haqi & 55 & 1 & 2.95 & 8.72 & 8.72 \\
\hline 5 & Alaikal & 53 & 1 & 0.95 & 0.91 & 0.91 \\
\hline 6 & Ade Ivan & 52 & 1 & -0.05 & 0.00 & 0.00 \\
\hline 7 & Hilman & 58 & 1 & 5.95 & 35.43 & 35.43 \\
\hline 8 & Ade Ryan & 52 & 1 & -0.05 & 0.00 & 0.00 \\
\hline 9 & Diki & 50 & 1 & -2.05 & 4.19 & 4.19 \\
\hline 10 & Edi & 50 & 1 & -2.05 & 4.19 & 4.19 \\
\hline 11 & Eriko & 53 & 1 & 0.95 & 0.91 & 0.91 \\
\hline 12 & Danang & 52 & 1 & -0.05 & 0.00 & 0.00 \\
\hline 13 & Fikri R & 53 & 1 & 0.95 & 0.91 & 0.91 \\
\hline 14 & Saipul & 52 & 1 & -0.05 & 0.00 & 0.00 \\
\hline 15 & Denka P & 53 & 1 & 0.95 & 0.91 & 0.91 \\
\hline 16 & Yusril & 52 & 1 & -0.05 & 0.00 & 0.00 \\
\hline 17 & Farid & 53 & 1 & 0.95 & 0.91 & 0.91 \\
\hline 18 & Ajiz & 54 & 1 & 1.95 & 3.81 & 3.81 \\
\hline 19 & Ranu & 53 & 1 & 0.95 & 0.91 & 0.91 \\
\hline 20 & Firi & 53 & 1 & 0.95 & 0.91 & 0.91 \\
\hline 21 & Yayan & 53 & 1 & 0.95 & 0.91 & 0.91 \\
\hline
\end{tabular}

Table 3. The Anthopometric data and The size of the finalization

\begin{tabular}{lcccc}
\hline \multicolumn{1}{c}{ Type of anthopometry } & Average & SD & $5^{\mathrm{TH}}$ & $95^{\mathrm{TH}}$ \\
\hline Knee Height & 52.05 & 1.57 & 49.46 & 54.63 \\
Fold Your Knees & 41.05 & 1.4 & 38.74 & 43.35 \\
Elbow Height On Sitting Position & 71.29 & 1.84 & 68.26 & 74.31 \\
Back Knee Half Food & 22.86 & 1.53 & 20.34 & 25.37 \\
Sleeve Length & 73.90 & 3.72 & 67.79 & 80.02 \\
Width Last Length & 30.76 & 1.56 & 28.20 & 33.33 \\
\hline
\end{tabular}


Tibuana

Journal of applied Industrial Engineering-University of PGRI Adi Buana

DOI : https://doi.org/10.36456/tibuana.4.01.3177.44-48

$p$-ISSN 2622-2027

$e$-ISSN 2622-2035

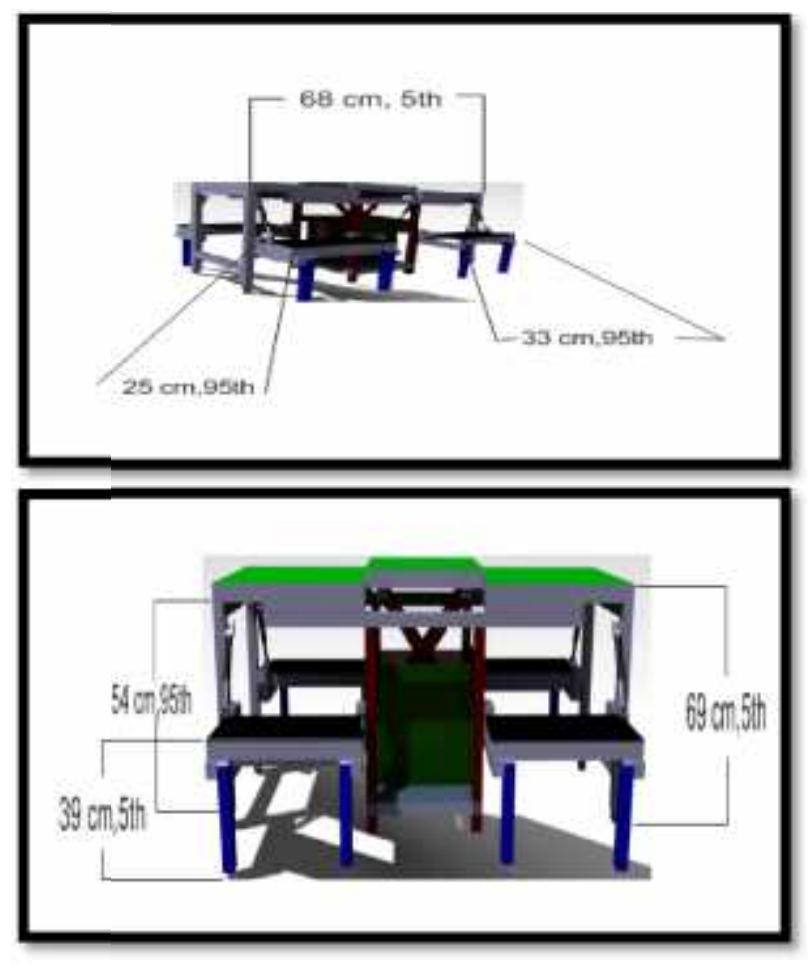

Figure 1: Table and Chair Design

- Mean $=\frac{\Sigma f}{N}=\frac{1}{2}=52,05$

- $\mathrm{Fx}=1093$

- $\mathrm{SD}=\sqrt{\frac{\sum f^{2}}{N}}=\sqrt{\frac{5,0}{2}}=1,57$

- $\quad$ Presentil $95=$ Rata" + 1,645.SD = 54,63

- Presentil $5=$ Rata" - 1,645.SD = 49,46

The chair flexibility table product design using the anthopometric method to minimize land use, there are several measures that refer to human anthopometry. These sizes include chair width of

\section{REFERENCES}

1. Elsa,M.A.S, Setiawan Andreas,P dan Rizqi (2017). Perancangan Kursi Makan Lipat
$25 \mathrm{~cm}$ in the 95th percentile, chair length of 33 $\mathrm{cm}$ in the 95th percentile, table length of $68 \mathrm{~cm}$ in the 5th percentile, chair height of $39 \mathrm{~cm}$ in the 5 th percentile, table height of $69 \mathrm{~cm}$ in the 5th

\section{Conclusion}

These products are suitable for use especially Asian people with a height of $150 \mathrm{~cm}$ to $175 \mathrm{~cm}$

Pada Ruang Makan Apartemen Minimalis. Jurnal Intra, Vol.5, No.2,909-918

2. Hasimjaya,J, Wibowo,M dan Wondo,D (2017). Kajian Antopometri \& Ergonomi Desain Mebel Pendidikan Anak Usia Dini 3- 
4 Tahun di Siwalankerto. Jurnal Intra, Vol.5, No.2, 449-459

3. Kusaini,Y.K, Husaini,M.A, dan Karyadi,D (1994). Antopometri Bayi Baru Lahir Dan Risiko Relatif Terhadap Kematian Neonatal. Balai Penelitian Kesehatan, 22(4)

4. McCormick,E.J dan Sanders,M.S (1993). Human Factors In Engineering And Design (7th ed). New York,NY, England: McgrawHill Book Company.
5. Reinhard,T.S dan Hidayat,T (2014). Desain Furnitur Meja dan Kursi Multifungsi Untuk Apartemen Tipe Studio. Jurnal Sains Dan Seni Pomits, Vol.3, No.1, 2337-3520.

6. Pramana, Y. B., Koesdijati, T., Huda, A. M., \& Subandowo, M. (2019). Redesain Mesin Parut Kelapa Menggunakan Motor Listrik 100 Watt. Seminar Nasional Hasil Riset dan Pengabdian, Ke-II , 408-412. 